\title{
Location effects across northeastern Europe on bioactive compounds in apple fruit
}

\begin{abstract}
Jonas Viškelis ${ }^{1}$, Nobertas Uselis ${ }^{1}$, Mindaugas Liaudanskas ${ }^{1,2}$, Juozas Lanauskas ${ }^{1}$, Pawel Bielicki ${ }^{3}$, Toivo Univer ${ }^{4}$, Janis Lepsis ${ }^{5}$ and Darius Kviklys ${ }^{1}$

${ }^{1}$ Institute of Horticulture, Lithuanian Research Centre for Agriculture and Forestry, Kauno 30, Babtai, Kaunas distr., Lithuania

${ }^{2}$ Medicinal Academy, Lithuanian University of Health Sciences, Eivenių 4, Kaunas, Lithuania

${ }^{3}$ Research Institute of Horticulture, Konstytucji 3 Maja 1/3, 96-100 Skierniewice, Poland

${ }^{4}$ Polli Horticultural Research Centre, Institute of Agricultural and Environmental Sciences, Estonian University of Life Sciences, Polli 69108, Karksi-Nuia, Viljandi county, Estonia

${ }^{5}$ Institute of Horticulture, Latvia University of Agriculture, Pure 3124, Tukuma distr., Latvia

e-mail: j.viskelis@Isdi.lt

A multi-location trial was performed in apple orchards planted in 2005 under a uniform scheme in Poland, Lithuania, Latvia and Estonia. The aim of this study was to evaluate the impact of the geographical apple-tree growing location on the accumulation of dominant bioactive compounds in apple fruits: phenolics and triterpenes as the most valuable substances for human health. The study included two apple cultivars, 'Auksis' and 'Ligol', on B.396 rootstock and was carried out from 2016 to 2018. Geographical apple-tree growing location had a significant impact on the composition and total content of the tested bioactive compounds in apple fruits. Increased accumulation of phenolic and triterpene compounds was recorded in the south-north direction. This could be explained by the different climate conditions in the trial locations: the sum of active temperatures gradually decreased by 200-300 ${ }^{\circ} \mathrm{C}$ in the south-north direction, and the vegetation period becomes shorter. Apples grown in Estonia, depending on the tested cultivar, had $77-139 \%$ more total phenolic compounds. Significant differences were recorded for all groups of phenolic compounds. The differences between the trial sites in accumulation of triterpene compounds were lower, although apples in at farthest north location had $18-32 \%$ more total triterpene compounds than apples grown in south.
\end{abstract}

Key words: geographical location, Malus $\mathrm{x}$ domestica, phenolic content, triterpene content

\section{Introduction}

Multi-location trials involving fruit growing are very rare due to their complicated trial setup and assurance of optimal management, along with the different financial possibilities of participating institutions. Previous and current studies of how geographical location impacts apple tree performance are mainly limited to rootstock trials (Maas and Wertheim 2004, Autio et al. 2008). The NC-140 project in the northern and central parts of the USA investigated the influence of rootstock on the growth, yields and fruit quality of fruit trees. In the Baltic region, such studies were also carried out during the implementation of the 'Baltic Fruit Rootstock Studies' project (Bite et al. 2004, Kviklys et al. 2013). All of these studies reported effects of rootstock in various climate conditions on tree vegetative growth, productivity characteristics and basic fruit quality parameters - specifically, fruit size, colour, firmness and soluble solid content. However, studies that measure the influence of apple tree growing location on the internal quality of the fruit (secondary metabolites, phytochemical composition) have not yet been performed.

Moreover, results from geographically distinct trial sites can be used to simulate some effects of possible climate change.

Two groups of bioactive compounds are the most important in apple fruits: phenolics and triterpenes. Phenolic compounds are beneficial to the human body due to their antioxidant properties, and apples are a good source of these compounds (Eberhardt et al. 2000, Wolfe et al. 2003). The following phenolic compounds of different groups were identified and quantified in apple extracts: quercetin glycosides (hyperoside, isoquercitrin, rutin, reynoutrin, avicularin, quercitrin), flavan-3-ol (procyanidin B1, procyanidin B2, procyanidin C1, (+)-catechin, (-)-epicatechin), phloridzin and chlorogenic acid. Research on biologically active compounds, especially phenols, in apples is limited to evaluations of different cultivars (Wojdyło et al. 2008, Vieira et al. 2009, Liaudanskas et al. 2015), organic and integrated growing systems (Hecke et al. 2006, Lanauskas et al. 2017), light effects (Drogoudi and Pantelidis 2011) and some apple tree stress factors such as drought, pathogens and soil salinity (Treutter 2010). We also conducted research to evaluate the effects of fruit tree nutrition (Lanauskas et al. 2017), rootstocks (Kviklys et al. 2014) and vegetation period (Liaudanskas et al. 2016) on the accumulation of phenolic compounds. 
Triterpenes are well known for their pharmacological properties (Fontanay et al. 2008). Triterpenic compounds are the biologically active compounds found in apples and are among the most promising and significant compounds for human health (Woźniak et al. 2015, Somova et al. 2003). One of the most important biological effects of triterpenic compounds in apple is strong anti-inflammatory activity (Andre et al. 2012, Cargnin and Gnoatto 2017). Triterpenic compounds protect the cardiovascular system (Han \& Bakovic 2015) and also lower blood glucose levels (He et al. 2014).

Despite the importance of these properties, triterpene compounds in apples are still under-researched. Our previous studies quantified the four triterpenic compounds - corosolic, betulinic, oleonolic and ursolic acids - which are the most common triterpenes found in apple peel (Butkevičiūtè et al. 2018, Viškelis et al. 2018).

The role of climate conditions/growing site on the content of bioactive compounds in apple fruits has still not been investigated. The aim of this study was to evaluate the impact of geographical apple tree growing location on the accumulation of the dominant bioactive compounds in apple fruits, specifically phenolics and triterpenes, as the most valuable substances for human health.

\section{Materials and methods}

\section{General site description and management}

Two apple cultivars, 'Auksis' and 'Ligol', grown on rootstock B.396 were tested from 2016 to 2018. The cultivars are commercially important in the Nordic or Central European countries. Cv. 'Auksis' is dominant in Lithuanian, Latvian and Estonian orchards, while cv. 'Ligol' is extensively planted in Poland, Lithuania and Latvia. Rootstock B.396 was chosen for its good adaptation to Nordic regions, due to its high winter hardiness and productivity as well as low alternate bearing index (Kviklys et al. 2016). Fruit samples of each cultivar were collected at 4 locations: the Research Institute of Horticulture, located at Skierniewice (51 $58^{\prime} \mathrm{N}, 20^{\circ} 09^{\prime} \mathrm{E}$ ), Poland; the Institute of Horticulture, at the Lithuanian Research Centre for Agriculture and Forestry in Babtai $\left(55^{\circ} 60^{\prime} \mathrm{N}, 23^{\circ} 48^{\prime} \mathrm{E}\right)$, Lithuania; the Institute of Horticulture, at Latvia University of Agriculture in Pure (57 $\left.02^{\prime} \mathrm{N}, 22^{\circ} 52^{\prime} \mathrm{E}\right)$, Latvia and Polli Research Centre $\left(58^{\circ} 67^{\prime} \mathrm{N}, 25^{\circ} 33^{\prime} \mathrm{E}\right)$, at the Institute of Agricultural and Environmental Sciences of the Estonian University of Life Sciences in Polli, Estonia (Fig. 1).

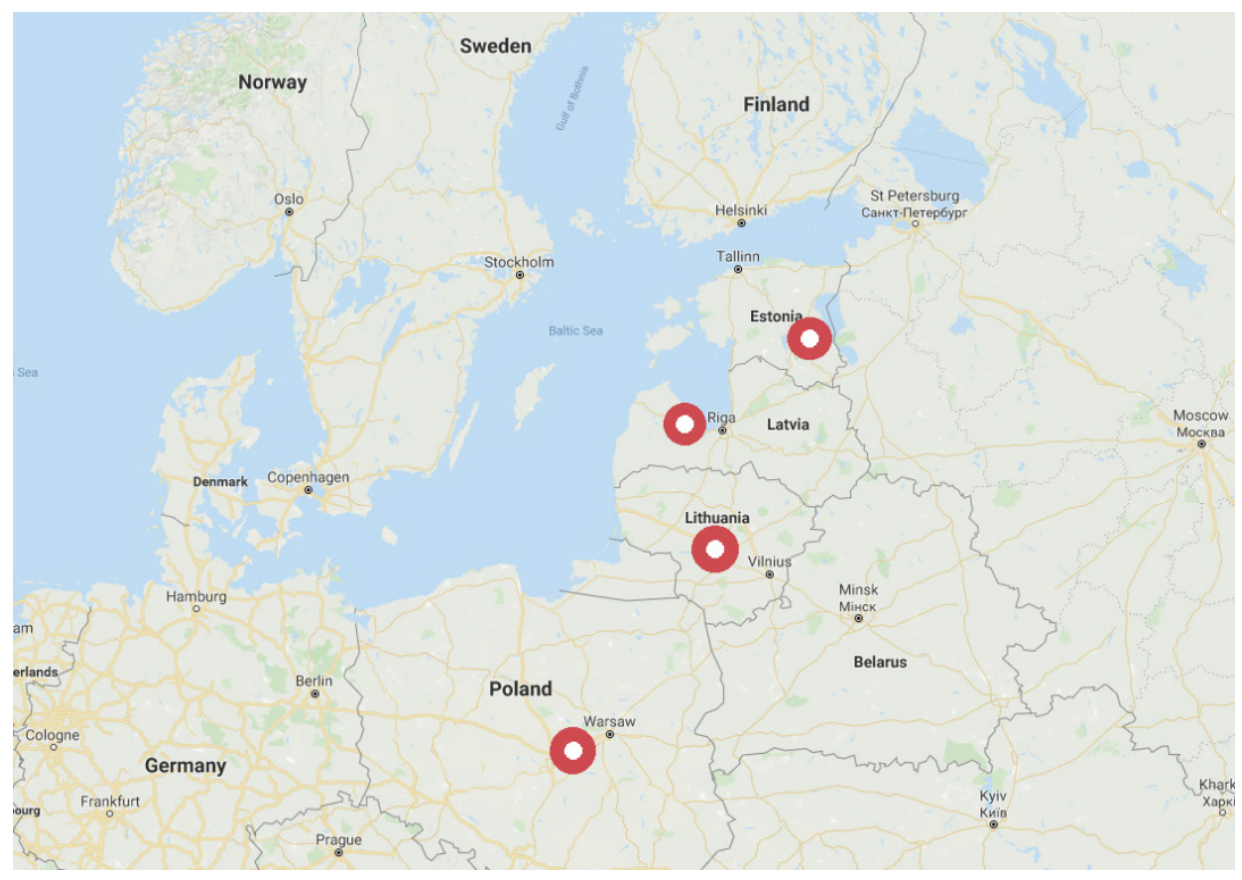

Fig. 1. Map of trial site locations (source: Google Maps)

All orchards were planted in spring 2005 under a uniform design in 4 replicates, with 3 apple trees per replicate. The planting distance was $4 \times 1.5 \mathrm{~m}$. Apple trees were trained as slender spindle. Climate conditions and soil properties differed between the trial locations. In Poland: soil - deep sandy-loam, $\mathrm{pH}-6.7$, humus $-1.4 \%, \mathrm{P}_{2} \mathrm{O}_{5}-195 \mathrm{mg} \mathrm{kg}{ }^{-1}$, 
$\mathrm{K}_{2} \mathrm{O}-190 \mathrm{mg} \mathrm{kg}^{-1}$, average annual precipitation $-550 \mathrm{~mm}$, average sum of active temperatures $\left(>10^{\circ} \mathrm{C}\right)-2550$ ${ }^{\circ} \mathrm{C}$. In Lithuania: soil - clay loam, $\mathrm{pH}-7.3$, humus - 2.8\%, $\mathrm{P}_{2} \mathrm{O}_{5}-255 \mathrm{mg} \mathrm{kg}^{-1}, \mathrm{~K}_{2} \mathrm{O}-230 \mathrm{mg} \mathrm{kg}^{-1}$, average annual precipitation $-630 \mathrm{~mm}$, average sum of active temperatures $-2300{ }^{\circ} \mathrm{C}$. In Latvia: soil - loamy sand, $\mathrm{pH}-6.4$, humus $-1.8 \%, \mathrm{P}_{2} \mathrm{O}_{5}-290 \mathrm{mg} \mathrm{kg}^{-1}, \mathrm{~K}_{2} \mathrm{O}-180 \mathrm{mg} \mathrm{kg}^{-1}$, average annual precipitation $-640 \mathrm{~mm}$, average sum of active temperatures $-2100{ }^{\circ} \mathrm{C}$. In Estonia: soil - clay loam, $\mathrm{pH}-5.3$, humus $-2.0 \%, \mathrm{P}_{2} \mathrm{O}_{5}-130 \mathrm{mg} \mathrm{kg}^{-1}, \mathrm{~K}_{2} \mathrm{O}-223$ $\mathrm{mg} \mathrm{kg}^{-1}$, average annual precipitation $-455 \mathrm{~mm}$, average sum of active temperatures $-1930{ }^{\circ} \mathrm{C}$. Fifty randomly selected apples were harvested at 1.2-1.8 m height above the ground from 3 apple trees from each experimental plot at the optimal harvest time, which was individually established for each cultivar and country: cv. 'Auksis' was harvested when the Streif index ranged between 0.13 and 0.16, and cv. 'Ligol' was harvested when the Streif index ranged between 0.09 and 0.12. Apple fruitlets were thinned manually after the June drop, leaving 1 apple per cluster for cv. 'Auksis' and 1-2 apples per cluster for cv. 'Ligol'.

\section{Analytical procedures}

Sample preparation: Each apple was cut in slices and peeled with a semi-automatic peeling and cutting machine AS 4 (Kronen $\mathrm{GmbH}$, Germany). The slices and peels were immediately frozen in a freezer (at $-35^{\circ} \mathrm{C}$ ) with air circulation and then lyophilized with a sublimator Zirbus $3 \times 4 \times 5$ (ZIRBUS technology GmbH, Germany) at a pressure of $0.01 \mathrm{mbar}$ (condenser temperature $-85^{\circ} \mathrm{C}$ ). The lyophilized apple slices and peels were ground to fine powder with a knife mill GM (Retsch $\mathrm{GmbH}$, Germany). Loss on drying before analysis was determined by drying the apple lyophilizate in a laboratory drying oven to complete evaporation of water and volatile compounds (temperature $-105^{\circ} \mathrm{C}$, the difference in weight between measurements - up to $0.01 \mathrm{~g}$ ) and by calculating the difference in raw material weight before and after drying. The data were recalculated for dry weight (DW).

Preparation of apple extracts for the determination of phenolic compounds: An amount of $2.5 \mathrm{~g}$ of lyophilized apple (peel and flesh) powder (exact weight) was weighed, added to $30 \mathrm{ml}$ of ethanol (70\%, v/v), and extracted in a Sonorex Digital $10 \mathrm{P}$ ultrasonic bath (Bandelin Electronic $\mathrm{GmbH}$, Germany) for 27 minutes at $45^{\circ} \mathrm{C}$. The extract was filtered through a membrane filter with a pore size of $0.22 \mu \mathrm{m}$ (Carl Roth $\mathrm{GmbH}$, Germany).

Preparation of apple extracts for the determination of triterpenic compounds: An amount of $1 \mathrm{~g}$ of lyophilized apple peel powder (exact weight) was weighed, added to $10 \mathrm{ml}$ of acetone (100\%, v/v), and extracted in a Sonorex Digital $10 \mathrm{P}$ ultrasonic bath (Bandelin Electronic $\mathrm{GmbH}$, Germany) for 10 minutes. The conditions of extraction (type of extraction, duration, temperature, solvent and its concentration) were chosen considering the results of extraction optimization (Butkevičiūtè et al. 2018). The extract was filtered through a membrane filter with a pore size of $0.22 \mu \mathrm{m}$ (Carl Roth $\mathrm{GmbH}$, Germany).

High Performance Liquid Chromatography (HPLC) method for the determination of phenolic compounds: A Waters e2695 chromatograph equipped with a Waters 2998 photodiode array detector (Waters, USA) was used for the HPLC analysis. Chromatographic separations were carried out by using a YMC-Pack ODS-A (5 $\mu$ m, C18, $250 \times 4.6$ $\mathrm{mm}$ ) column equipped with a YMC-Triart $(5 \mu \mathrm{m}, \mathrm{C} 18,10 \times 3.0 \mathrm{~mm}$ ) pre-column (YMC Europe GmbH, Germany). The column was operated at a constant temperature of $25^{\circ} \mathrm{C}$. The volume of the injection was $10 \mu \mathrm{l}$. The flow rate was $1 \mathrm{ml} \mathrm{min}{ }^{-1}$, and gradient elution was used. The mobile phase consisted of $2 \%(\mathrm{v} / \mathrm{v}$ ) acetic acid in water (solvent A) and $100 \%(v / v)$ acetonitrile (solvent B). The following conditions of elution were applied: 0-30 minutes, 3-15\% B; 30-45 minutes, 15-25\% B; 45-50 minutes, 25-50\% B; and 50-55 minutes, 50-95\% B. The identification of the chromatographic peaks was achieved by the retention times and spectral characteristics $(\lambda=200-400 \mathrm{~nm})$ of the eluting peaks with those of the reference compounds. Dihydrochalcones and flavan-3-ols were quantified at 280 $\mathrm{nm}$, phenolic acids at $320 \mathrm{~nm}$ and flavonols at $360 \mathrm{~nm}$.

HPLC method for the determination of triterpenic compounds: A chromatograph Waters 2695 equipped with a detector Waters 2998 PDA (Waters, USA) was used for HPLC analysis. Chromatographic separation was managed, chromatograms were recorded, and data were processed with the software Empower ${ }^{\circledR}$ v.3.0 (Waters, USA). Chromatographic separations were carried out by using an $\operatorname{ACE}^{\circledR}(5 \mu \mathrm{m}, \mathrm{C} 18,250 \times 4.6 \mathrm{~mm})$ column. The column was operated at a constant temperature of $25^{\circ} \mathrm{C}$. The volume of the extract being investigated was $10 \mu \mathrm{l}$. The flow rate was $1 \mathrm{ml} \mathrm{min}{ }^{-1}$, and isocratic elution was used. The mobile phase consisted of $88 \%$ acetonitrile (solvent $\mathrm{A}$ ) and $12 \%$ water (solvent B). The duration of the analysis was 15 minutes. The identification of the chromatographic peaks was achieved by comparing the retention times and spectral characteristics $(\lambda=200-400 \mathrm{~nm})$ of the eluting peaks with those of reference compounds. The compounds identified were confirmed by spiking the sample with the standard compound and monitoring the changes in the peak shape and spectral characteristics. For quantitative analysis, a calibration curve was obtained by injection of known concentrations of different standard compounds. 
The concentrations of triterpenic compounds, identified in the apple peel extracts, were within the limits of calibration curves. Triterpenic compounds were quantified at $205 \mathrm{~nm}$. The concentration of triterpene compounds was calculated based on the peak areas by using standard compounds.

\section{Statistical analyses}

All of the experiments were carried out in 4 replications each year. Since there were no year-location interactions, the data are presented as the averages of 3 years of experimentation. The means and standard deviations were calculated with the STATISTICA 10 (StatSoft, Inc., USA) and Excel (Microsoft, USA) software packages. One-way analysis of variance (ANOVA) along with post-hoc Tukey's HSD tests were employed for statistical analysis. Differences were considered to be significant at $p<0.05$.

\section{Results}

Geographical apple tree growing location influenced the composition of phenolic compounds in apple fruits (Table 1). The amount of quercetin glycosides in the 'Auksis' apples tended to increase when fruits grew in orchards in the north-east direction. Apples grown in Poland accumulated $48 \%$ less of these compounds than apples grown in Estonia (it varied from $0.27 \pm 0.025 \mathrm{mg} \mathrm{g}^{-1} \mathrm{DW}$ in Poland to $0.52 \pm 0.234 \mathrm{mg} \mathrm{g}^{-1} \mathrm{DW}$ in Estonia). Flavan-3-ols, phloridzin and chlorogenic acid also tended to increase in the same trend. This trend was also clearly reflected in the total amount of investigated phenolic compounds. 'Auksis' apples grown in Estonia had 2.4 times more phenolic compounds than apples grown in Poland (which varied from $2.68 \pm 0.404 \mathrm{mg} \mathrm{g}^{-1} \mathrm{DW}$ in Poland to $6.40 \pm 0.847 \mathrm{mg}$ $\mathrm{g}^{-1} \mathrm{DW}$ in Estonia). The phenolic compound content in fruits from Lithuania and Latvia were at intermediate levels.

The content of phenolic compounds for the 'Ligol' cultivar (Table 2) was also highest in apples grown in Estonia - here, they accumulated about $77 \%$ more phenols than in Poland or Lithuania (varying from $2.17 \pm 0.534 \mathrm{mg} \mathrm{g}^{-1}$ DW in Poland to $3.84 \pm 0.643 \mathrm{mg} \mathrm{g}^{-1} \mathrm{DW}$ in Estonia).

Table 1. Amount of investigated phenolic compounds ( $\left.\mathrm{mg} \mathrm{g}^{-1} \mathrm{DW}\right)$ in apples grown in different geographical locations (cv. 'Auksis', average 2016-2018)

\begin{tabular}{|c|c|c|c|c|}
\hline \multirow[t]{2}{*}{ Phenolic compounds, $\mathrm{mg} \mathrm{g}^{-1} \mathrm{DW}$} & \multicolumn{4}{|c|}{ Geographical location of 'Auksis' apple-trees } \\
\hline & Poland & Lithuania & Latvia & Estonia \\
\hline Hyperoside & $0,09 \pm 0,013^{b}$ & $0,11 \pm 0,055^{b}$ & $0,11 \pm 0,050$ ab & $0,17 \pm 0,077$ \\
\hline Isoquercitrin & $0,03 \pm 0,002^{b}$ & $0,03 \pm 0,007^{b}$ & $0,03 \pm 0,007^{b}$ & $0,04 \pm 0,012$ a \\
\hline Rutin & $0,01 \pm 0,001^{\mathrm{a}}$ & $0,02 \pm 0,004{ }^{a}$ & $0,01 \pm 0,002^{a}$ & $0,02 \pm 0,004^{a}$ \\
\hline Reynoutrin & $0,03 \pm 0,005^{b}$ & $0,03 \pm 0,013^{b}$ & $0,04 \pm 0,017^{b}$ & $0,07 \pm 0,034^{a}$ \\
\hline Avicularin & $0,07 \pm 0,007^{b}$ & $0,08 \pm 0,021^{b}$ & $0,10 \pm 0,029^{b}$ & $0,16 \pm 0,067^{a}$ \\
\hline Quercitrin & $0,04 \pm 0,012 \mathrm{ab}$ & $0,04 \pm 0,013$ ab & $0,03 \pm 0,010^{b}$ & $0,06 \pm 0,042^{a}$ \\
\hline Quercetin glycosides & $0,27 \pm 0,025^{b}$ & $0,32 \pm 0,111^{b}$ & $0,33 \pm 0,108^{b}$ & $0,52 \pm 0,234^{a}$ \\
\hline Procyanidin B1 & $0,02 \pm 0,006^{b}$ & $0,09 \pm 0,096^{a b}$ & $0,08 \pm 0,063 a b$ & $0,13 \pm 0,095^{a}$ \\
\hline Procyanidin B2 & $0,38 \pm 0,101^{c}$ & $0,65 \pm 0,287^{b}$ & $0,58 \pm 0,353 \mathrm{bc}$ & $1,08 \pm 0,152^{a}$ \\
\hline Procyanidin C1 & $0,14 \pm 0,045^{b}$ & $0,30 \pm 0,181^{a}$ & $0,27 \pm 0,079 a b$ & $0,42 \pm 0,222^{a}$ \\
\hline (+)-Catechin & $0,06 \pm 0,028^{c}$ & $0,13 \pm 0,083^{b}$ & $0,17 \pm 0,028^{b}$ & $0,24 \pm 0,023^{a}$ \\
\hline (-)-Epicatechin & $0,27 \pm 0,075^{d}$ & $0,43 \pm 0,133^{c}$ & $0,57 \pm 0,099^{b}$ & $0,77 \pm 0,085^{a}$ \\
\hline Flavan-3-ol's & $0,86 \pm 0,170^{c}$ & $1,60 \pm 0,763^{b}$ & $1,68 \pm 0,367^{b}$ & $2,64 \pm 0,439^{a}$ \\
\hline Phlorizin & $0,08 \pm 0,009^{b}$ & $0,11 \pm 0,017^{b}$ & $0,09 \pm 0,046^{b}$ & $0,18 \pm 0,049^{a}$ \\
\hline Chlorogenic acid & $1,47 \pm 0,227^{c}$ & $2,09 \pm 0,429^{b}$ & $2,29 \pm 0,303^{b}$ & $3,06 \pm 0,241^{a}$ \\
\hline Total & $2,68 \pm 0,404^{c}$ & $4,11 \pm 1,104^{b}$ & $4,39 \pm 0,683^{b}$ & $6,40 \pm 0,847^{a}$ \\
\hline
\end{tabular}

The different letters on the same line indicate statistically significant differences between the individual compounds in the apple samples $(p<0.05)$.

Geographical apple tree growing location also had an effect on the accumulation of triterpene compounds in fruits. The 'Auksis' apple cultivar (Table 3) grown in Poland had 32\% less triterpene compounds than fruits grown in Esto- 
nia (varying from $9.10 \pm 2.428 \mathrm{mg} \mathrm{g}^{-1} \mathrm{DW}$ in Poland to $13.32 \pm 1.179 \mathrm{mg} \mathrm{g}^{-1} \mathrm{DW}$ in Estonia). A similar trend was observed for the 'Ligol' cultivar (Table 4). Apples grown in Poland accumulated 18\% less triterpene compounds than apples grown in Estonia (varying from 14. $11.97 \pm 1.066 \mathrm{mg} \mathrm{g}^{-1} \mathrm{DW}$ in Poland to $68 \pm 0.578 \mathrm{mg} \mathrm{g}^{-1} \mathrm{DW}$ in Estonia).

Table 2. Amount of investigated phenolic compounds ( $\left.\mathrm{mg} \mathrm{g}^{-1} \mathrm{DW}\right)$ in apples grown in different geographical locations (cv. 'Ligol', average 2016-2018)

\begin{tabular}{|c|c|c|c|c|}
\hline \multirow{2}{*}{$\begin{array}{c}\text { Phenolic compounds, } \\
\mathrm{mg} \mathrm{g}^{-1} \mathrm{DW}\end{array}$} & \multicolumn{4}{|c|}{ Geographical location of 'Ligol' apple-trees } \\
\hline & Poland & Lithuania & Latvia & Estonia \\
\hline Hyperoside & $0,15 \pm 0,034^{b}$ & $0,09 \pm 0,021^{c}$ & $0,22 \pm 0,081^{a}$ & $0,23 \pm 0,054{ }^{a}$ \\
\hline Isoquercitrin & $0,04 \pm 0,007 \mathrm{bc}$ & $0,03 \pm 0,003^{c}$ & $0,05 \pm 0,018$ a & $0,04 \pm 0,004$ ab \\
\hline Rutin & $0,02 \pm 0,006^{a}$ & $0,02 \pm 0,003^{b}$ & $0,03 \pm 0,010^{a}$ & $0,02 \pm 0,004{ }^{a b}$ \\
\hline Reynoutrin & $0,03 \pm 0,009^{b}$ & $0,02 \pm 0,004^{b}$ & $0,06 \pm 0,024{ }^{a}$ & $0,07 \pm 0,012^{a}$ \\
\hline Avicularin & $0,08 \pm 0,015^{b}$ & $0,06 \pm 0,007^{b}$ & $0,13 \pm 0,040^{a}$ & $0,14 \pm 0,020^{a}$ \\
\hline Quercitrin & $0,10 \pm 0,024 b c$ & $0,08 \pm 0,013^{c}$ & $0,12 \pm 0,048^{a b}$ & $0,13 \pm 0,027^{a}$ \\
\hline Quercetin glycosides & $0,43 \pm 0,089^{b}$ & $0,30 \pm 0,044^{c}$ & $0,61 \pm 0,215^{a}$ & $0,63 \pm 0,098^{a}$ \\
\hline Procyanidin B1 & $0,02 \pm 0,016^{a}$ & $0,02 \pm 0,028^{a}$ & $0,03 \pm 0,026^{a}$ & $0,03 \pm 0,046^{a}$ \\
\hline Procyanidin B2 & $0,44 \pm 0,119^{b}$ & $0,41 \pm 0,142^{b}$ & $0,60 \pm 0,179$ a & $0,64 \pm 0,173^{a}$ \\
\hline Procyanidin C1 & $0,20 \pm 0,098^{a}$ & $0,17 \pm 0,101^{a}$ & $0,27 \pm 0,139$ a & $0,27 \pm 0,176^{a}$ \\
\hline (+)-Catechin & $0,03 \pm 0,009^{b}$ & $0,04 \pm 0,025^{b}$ & $0,09 \pm 0,029$ a & $0,09 \pm 0,025^{a}$ \\
\hline (-)-Epicatechin & $0,27 \pm 0,061^{b}$ & $0,29 \pm 0,089^{b}$ & $0,58 \pm 0,167^{a}$ & $0,56 \pm 0,071^{a}$ \\
\hline Flavan-3-ol's & $0,95 \pm 0,251^{b}$ & $0,94 \pm 0,378^{b}$ & $1,57 \pm 0,468^{a}$ & $1,61 \pm 0,426^{a}$ \\
\hline Phlorizin & $0,07 \pm 0,021^{b}$ & $0,08 \pm 0,014^{b}$ & $0,14 \pm 0,034^{a}$ & $0,15 \pm 0,038^{a}$ \\
\hline Chlorogenic acid & $0,72 \pm 0,223^{b}$ & $0,79 \pm 0,090^{b}$ & $1,39 \pm 0,370^{a}$ & $1,45 \pm 0,165^{a}$ \\
\hline Total & $2,17 \pm 0,534^{b}$ & $2,10 \pm 0,471^{b}$ & $3,71 \pm 1,057^{a}$ & $3,84 \pm 0,643^{a}$ \\
\hline
\end{tabular}

The different letters on the same line indicate statistically significant differences between the individual compounds in the apple samples $(p<0.05)$.

Table 3. Amount of investigated triterpene compounds ( $\mathrm{mg} \mathrm{g}^{-1} \mathrm{DW}$ ) in apple peel grown in different geographical locations (cv. 'Auksis', average 2016-2018)

\begin{tabular}{|c|c|c|c|c|}
\hline \multirow[t]{2}{*}{$\begin{array}{c}\text { Triterpene compounds, } \mathrm{mg} \\
\mathrm{g}^{-1} \mathrm{DW}\end{array}$} & \multicolumn{4}{|c|}{ Geographical location of 'Auksis' apple-trees } \\
\hline & Poland & Lithuania & Latvia & Estonia \\
\hline Corosolic acid & $0,34 \pm 0,120^{c}$ & $0,42 \pm 0,135 \mathrm{bc}$ & $0,61 \pm 0,098^{a}$ & $0,51 \pm 0,021 \mathrm{ab}$ \\
\hline Betulinic acid & $0,10 \pm 0,030^{a}$ & $0,12 \pm 0,044^{a}$ & $0,14 \pm 0,048^{a}$ & $0,11 \pm 0,004^{\text {a }}$ \\
\hline Oleonolic acid & $1,50 \pm 0,334^{b}$ & $2,02 \pm 0,403^{a}$ & $2,32 \pm 0,443^{a}$ & $2,15 \pm 0,287^{a}$ \\
\hline Ursolic acid & $7,16 \pm 1,978^{b}$ & $9,29 \pm 2,085$ ab & $9,84 \pm 1,627$ ab & $10,55 \pm 0,896$ ab \\
\hline Total & $9,10 \pm 2,428^{b}$ & $11,84 \pm 2,658$ ab & $12,91 \pm 2,209^{a}$ & $13,32 \pm 1,179 a$ \\
\hline
\end{tabular}

The different letters on the same line indicate statistically significant differences between the individual compounds in the apple samples $(p<0.05)$.

Table 4. Amount of investigated triterpene compounds ( $\left.\mathrm{mg} \mathrm{g}^{-1} \mathrm{DW}\right)$ in apple peel grown in different geographical locations (cv. 'Ligol', average 2016-2018)

\begin{tabular}{|c|c|c|c|c|}
\hline \multirow{2}{*}{$\begin{array}{c}\text { Triterpene compounds, } \\
\mathrm{mg} \mathrm{g}^{-1} \mathrm{DW}\end{array}$} & \multicolumn{4}{|c|}{ Geographical location of 'Ligol' apple-trees } \\
\hline & Poland & Lithuania & Latvia & Estonia \\
\hline Corosolic acid & $1,09 \pm 0,1399^{b}$ & $1,67 \pm 0,260^{a}$ & $0,88 \pm 0,178^{b}$ & $0,88 \pm 0,050^{b}$ \\
\hline Betulinic acid & $0,11 \pm 0,011^{b}$ & $0,16 \pm 0,010^{a}$ & $0,11 \pm 0,034^{b}$ & $0,14 \pm 0,024{ }^{a}$ \\
\hline Oleonolic acid & $1,86 \pm 0,291^{b}$ & $2,26 \pm 0,197^{a}$ & $2,25 \pm 0,285^{a}$ & $2,49 \pm 0,191^{a}$ \\
\hline Ursolic acid & $8,91 \pm 0,667^{c}$ & $9,51 \pm 0,487 \mathrm{bc}$ & $9,99 \pm 0,898^{b}$ & $11,16 \pm 0,424^{a}$ \\
\hline Total & $11,97 \pm 1,066^{c}$ & $13,60 \pm 0,849 a b$ & $13,23 \pm 1,363 \mathrm{bc}$ & $14,68 \pm 0,578^{a}$ \\
\hline
\end{tabular}

The different letters on the same line indicate statistically significant differences between the individual compounds in the apple samples $(p<0.05)$. 


\section{Discussion}

New findings about apples' nutritional value are especially important when facing the overproduction of apples in the world market and decreases in fruit prices. New scientific results on fruit quality parameters and benefits could lead to increased apple consumption.

Greater accumulation of phenolics occurs under stress conditions such as drought, disease damage and lack of nutrients (Treutter 2010, Lanauskas et al. 2017). Due to Estonia having the least favourable growth conditions for apple trees, these apple trees, from both cultivars, accumulated the highest content of phenolic compounds. This can be explained by the apple trees' response to stress caused by adverse climatic conditions (Winkel-Shirley 2002). In our study, the sum of active temperatures gradually decreased by $200-300{ }^{\circ} \mathrm{C}$ in the south-north direction.

Earlier reported results from the same orchards demonstrated significantly better apple coloration when heading north due to greater contrast between day and night temperatures close to fruit harvest time (Kviklys et al. 2013). Better-coloured apples accumulate higher content of phenolic compounds (Drogoudi and Pantelidis 2011), which is another explanation for the higher pharmaceutical value of apples grown in northern conditions.

In analysing both cultivars, the difference in total content of phenolic compounds was significant. On average for all locations, cv. 'Auksis' accumulated 59\% more total phenols than cv. 'Ligol'. Such cultivar-dependant differences have also been reported in our previous studies (Liaudanskas et al. 2014, 2015). The total content of investigated phenolic compounds established for both tested cultivars in the present study corresponds to the previously reported content. Although the increase in total phenols in the south-north direction was significant for both tested cultivars, the absolute increment also depended on the cultivar. In comparing the two most distant places, Poland and Estonia, cv. 'Auksis' apples in Estonia accumulated 139\% more phenolic compounds, whereas cv. 'Ligol' accumulated $77 \%$ more. These differences between cultivars could be explained by the different origins of these cultivars and their differing gene expression in their respective climatic conditions.

Triterpenes are a large group of terpenoid compounds. Corosolic, betulinic, oleanolic and ursolic acids are typical representatives of pentacyclic triterpenes and are widely distributed throughout the plant kingdom and in food products. Thirteen triterpenoids have been identified in apple peels (He and Liu 2007), but the highest concentrations found in apple peels were of oleonolic and ursolic acids (Cefarelli et al. 2006), which also agrees with the findings of our study.

Lv et al. (2015) showed that oleonolic and ursolic acid concentrations were higher in the peels of fruits from the shaded side than from the sun-exposed side. A negative relation between triterpenes and sun exposition was established. Lower sun radiation and shorter vegetation period could be one of the reasons why the accumulation of triterpene compounds becomes more intense in orchards further north, reaching the highest values in Estonia.

Some researchers have shown that differences between shaded and sun-exposed fruits cause different wax formation and structure both qualitatively and quantitatively (Tahir et al. 2009). Fruit wax formation can be linked to triterpene concentration and explains the higher triterpene concentration in cv. 'Ligol' apples, which naturally have waxier peels than cv. 'Auksis'.

In evaluating apple productivity data previously reported from the same trial, a tendency of lower yield and smaller fruits but better fruit colouring for cv. 'Ligol' was established in the south-north direction (Kviklys et al. 2013). Similar tendencies were found for cv. 'Auksis' (unpublished results). On the other hand, as established by our study, a northern climate is more favourable for faster accumulation of bioactive compounds in apple fruits. The distances between the trial locations in Poland and Lithuania and Lithuania and Estonia are around $400 \mathrm{~km}$. Changes to climatic conditions in such a distance are sufficient to significantly change the accumulation patterns of bioactive compounds.

\section{Conclusions}

Geographical apple tree growing location had a significant impact on the composition and total content of phenolic and triterpene compounds in apple fruits. Gradually increased accumulation of bioactive compounds was recorded in the south-north direction. 
'Auksis' apples grown in Estonia accumulated 139\%, and 'Ligol' apples 77\%, more total phenolic compounds compared to apples grown in Poland. Significant differences were recorded for all groups of phenolic compounds.

Depending on the cultivar, apples grown at the northernmost location (Estonia) had $18-32 \%$ more total triterpene compounds than apples grown in the southernmost location (Poland).

\section{Acknowledgments}

This work was supported by a grant from the Research Council of Lithuania, project No.S-MIP-17-8.

\section{References}

Andre, C.M., Greenwood, J.M., Walker, E.G., Rassam, M., Sullivan, M., Evers, D., Perry, N.B. \& Laing, W.A. 2012. Anti-inflammatory procyanidins and triterpenes in 109 apple varieties. Journal of Agricultural and Food Chemistry 60: 10546-10554. https:// doi.org/10.1021/jf302809k

Autio, W., Robinson, T., Cowgill, W., Hampson, C., Kushad, M., Masabni, J., Quezada, P.R., Perry, R. \& Rom, C. 2008. Performance of 'Gala' apple trees on Supporter 4, P.14, and different strains of B.9, M.9 and M.26 rootstocks: A five-year report on the 2002 NC-140 Apple Rootstock Trial. Journal of the American Pomological Society 62: 119-128.

Bite, A., Kviklys, D., Univer, T., \& Lukut, T. 2004. The beginning of the project "Baltic fruit rootstock studies". Acta Horticulturae 658: 437-440. https://doi.org/10.17660/ActaHortic.2004.658.64

Butkevičiūtè, A., Liaudanskas, M., Kviklys, D., Zymonè, K., Raudonis, R., Viškelis, J., Uselis, N. \& Janulis, V. 2018. Detection and analysis of triterpenic compounds in apple extracts. International Journal of Food Properties 21: 1716-1727. https://doi.org/10 $.1080 / 10942912.2018 .1506478$

Cargnin, S.T. \& Gnoatto, S.B. 2017. Ursolic acid from apple pomace and traditional plants: a valuable triterpenoid with functional properties. Food Chemistry 220: 477-489. https://doi.org/10.1016/j.foodchem.2016.10.029

Cefarelli, G., D’Abrosca, B., Fiorentino, A., Izzo, A., Mastellone, C., Pacifico, S. \& Piscopo, V. 2006. Free-Radical-Scavenging and Antioxidant Activities of Secondary Metabolites from Reddened Cv. Annurca Apple Fruits. Journal of Agricultural and Food Chemistry 54: 803-809. https://doi.org/10.1021/jf052632g

Drogoudi, P.D. \& Pantelidis G. 2011. Effect of position on canopy and harvest time on fruit physio-chemical and antioxidant properties in different apple cultivars. Scientia Horticulturae 129: 752-760. https://doi.org/10.1016/j.scienta.2011.05.036

Eberhardt, M.V., Lee, C.Y. \& Liu, R.H. 2000. Antioxidant activity of fresh apples. Nature 405: 903-904. https://doi. org/10.1038/35016151

Fontanay, S., Grare, M., Mayer, J., Finance, C. \& Duval, R.E. 2008. Ursolic, oleanolic and betulinic acids: Antibacterial spectra and selectivity indexes. Journal of Ethnopharmacology 120: 272-276. https://doi.org/10.1016/j.jep.2008.09.001

Han, N. \& Bakovic, M. 2015. Biologically active triterpenoids and their cardioprotective and anti- inflammatory effects. Journal of Bioanalysis \& Biomedicine 12: 3-11.

He, Q.Q., Yang, L., Zhang, J.Y., Ma, J.N. \& Ma, C.M. 2014. Chemical constituents of gold-red apple and their $\alpha$-glucosidase inhibitory activities. Journal of Food Science 79: 970-1983. https://doi.org/10.1111/1750-3841.12599

He, X. \& Liu, R. H. 2007. Triterpenoids Isolated from Apple Peels Have Potent Antiproliferative Activity and May Be Partially Responsible for Apple's Anticancer Activity. Journal of Agricultural and Food Chemistry 55: 4366-4370. https://doi.org/10.1021/jf063563o

Hecke, K., Herbinger, K., Veberic, R., Trobec, M., Toplak, H., Štampar, F., Keppel, H. \& Grill, D. 2006. Sugar-, acid- and phenol contents in apple cultivars from organic and integrated fruit cultivation. European Journal of Clinical Nutrition 60: 1136-1140. https://doi.org/10.1038/sj.ejcn.1602430

Kviklys, D., Čeidaitè, A., Lanauskas, J., Uselis, N., \& Samuolienė, G. 2016. The effect of rootstock on apple tree bearing stability in a cooler climate. Agricultural and food science 25:81-88. https://doi.org/10.23986/afsci.53381

Kviklys, D., Kviklienè, N., Bielicki, P., Bite, A., Lepsis, J., Univer, T., Univer, N., Uselis, N. \& Lanauskas, J. 2013. Baltic fruit rootstock studies: evaluation of apple (Malus domestica Borkh.) new rootstocks. Zemdirbyste-Agriculture 100: 441-446. https://doi. org/10.13080/z-a.2013.100.056

Kviklys, D., Liaudanskas, M., Janulis, V., Viškelis, P., Rubinskienė, M., Lanauskas, J. \& Uselis, N. 2014. Rootstock genotype determines phenol content in apple fruits. Plant, Soil and Environment 60: 234-240. https://doi.org/10.17221/71/2014-PSE

Lanauskas, J., Kviklys, D., Liaudanskas, M., Janulis, V., Uselis, N., Viškelis, J. \& Viškelis, P. 2017. Lower nitrogen nutrition determined higher phenolic content of organic apples. Horticultural Science 44: 113-119

Liaudanskas, M., Brunevičiūtė, R., Gaivelytė, K., Viškelis, J., Viškelis, P., Kviklys, D. \& Janulis, V. 2016. Seasonal Variation of Qualitative and Quantitative Composition of Phenolic Compounds and Antioxidant Activity in Apple (Malus domestica Borkh.) Fruits. International Journal of Biochemistry Research \& Review 14: 1-13. https://doi.org/10.9734/IJBCRR/2016/28856

Liaudanskas, M., Viškelis, P., Jakštas, V., Raudonis, R., Kviklys, D., Milašius, A. \& Janulis, V. 2014. Application of an optimized HPLC method for the detection of various phenolic compounds in apples from Lithuanian cultivars. Journal of Chemistry 2014: 542121. https://doi.org/10.1155/2014/542121

Liaudanskas, M., Viškelis, P., Kviklys, D., Raudonis, R. \& Janulis, V. 2015. A comparative study of phenolic content in apple fruits. International Journal of Food Properties 18: 945-953. https://doi.org/10.1080/10942912.2014.911311 
LV, Y., Tahir, I.I. \& Olsson, M.E. 2015. Factors affecting the content of the ursolic and oleanolic acid in apple peel: influence of cultivars, sun exposure, storage conditions, bruising and Penicillium expansum infection. Journal of the Science of Food and Agriculture 96: 2161-2169. https://doi.org/10.1002/jsfa.7332

Maas, F.M. \& Wertheim, S.J. 2004. A multi-site rootstock trial with the apple cultivars 'Cox's Orange Pippin' and 'Jonagold'. Acta Horticulturae 658: 177-184. https://doi.org/10.17660/ActaHortic.2004.658.25

Somova, L.O., Nadar, A., Rammanan, P. \& Shode, F.O. 2003. Cardiovascular, Antihyperlipidemic and Antioxidant Effects of Oleanolic and Ursolic Acids in Experimental Hypertension. Phytomedicine: International Journal of Phytotherapy and Phytopharmacology 10: 115-121. https://doi.org/10.1078/094471103321659807

Tahir, I.I., Johansson, E. \& Olsson, M.E. 2009. Improvement of apple quality and storability by a combination of heat treatment and controlled atmosphere storage. HortScience 44: 1648-1654. https://doi.org/10.21273/HORTSCI.44.6.1648

Treutter, D. 2010. Managing Phenol Contents in Crop Plants by Phytochemical Farming and Breeding-Visions and Constraints. International Journal of Molecular Sciences 11: 807-857. https://doi.org/10.3390/ijms11030807

Vieira, F.G., Borges, G.D., Copetti, C., Amboni, R.D., Denardi, F. \& Fett, R. 2009. Physicochemical and antioxidant properties of six apple cultivars (Malus domestica Borkh.) grown in southern Brazil. Scientia Horticulturae 122: 421-425. https://doi.org/10.1016/j. scienta.2009.06.012

Viškelis, J., Uselis, N., Liaudanskas, M., Janulis, V., Bielicki, P., Univer, T., Lepsis, J. \& Kviklys, D. 2018. Triterpenic acid content in the fruit peel of Malus $\times$ domestica Borkh. depends on the growing technology. Zemdirbyste-Agriculture 105: 71-78. https://doi. org/10.13080/z-a.2018.105.010

Winkel-Shirley, B. 2002. Biosynthesis of flavonoids and effects of stress. Current Opinion in Plant Biology 5: 218-223. https://doi. org/10.1016/S1369-5266(02)00256-X

Wojdyło, A., Oszmiański, J. \& Laskowski, P. 2008. Polyphenolic compounds and antioxidant activity of new and old apple varieties. Journal of Agricultural and Food Chemistry 56: 6520-6530. https://doi.org/10.1021/jf800510j

Wolfe, K., Wu, X. \& Liu, R.H. 2003. Antioxidant activity of apple peels. Journal of Agricultural and Food Chemistry 51: 609-614. https://doi.org/10.1021/jf020782a

Woźniak, Ł., Skąpska, S. \& Marszałek, K. 2015. Ursolic Acid - a Pentacyclic Triterpenoid with a Wide Spectrum of Pharmacological Activities. Molecules 20: 20614-20641. https://doi.org/10.3390/molecules201119721 